\title{
ND
}

237

.W6

F73

The Freer Gallery of Art of the

SMITHSONIAN INSTITUTION in

\section{THE WHISTLER PEACOCK ROOM}

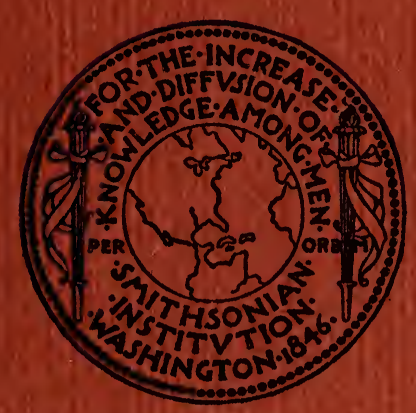

Publication 4024

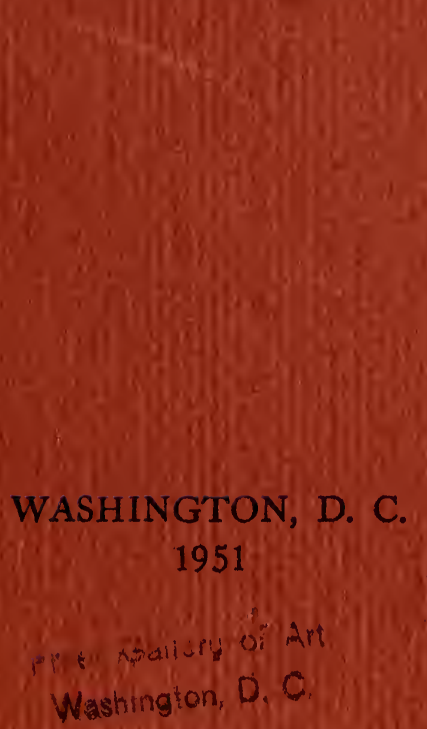




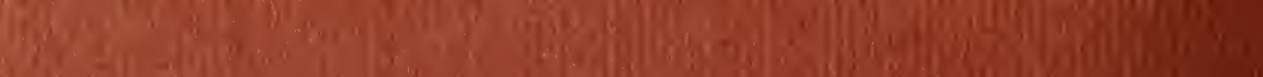

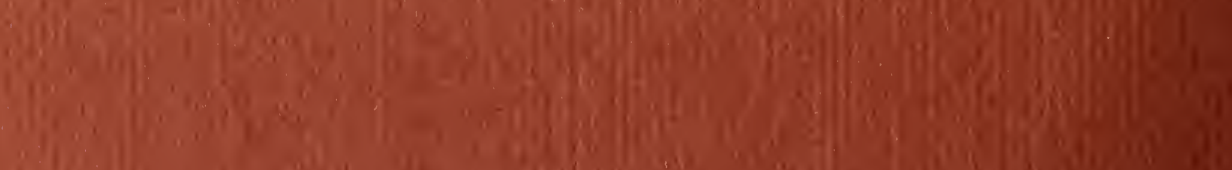
1

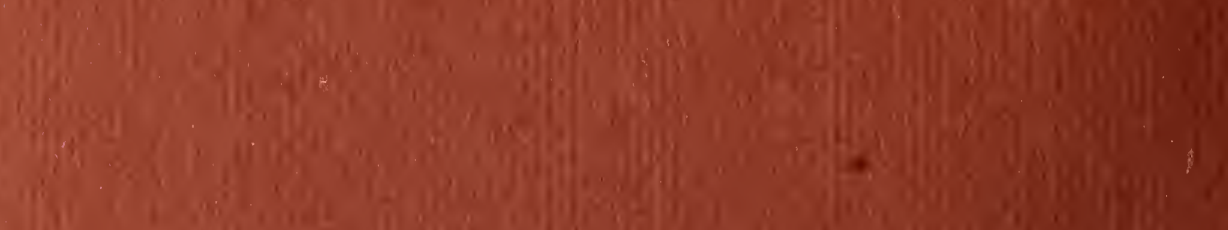
(1)

$$
\begin{aligned}
& \text { mingersing } \\
& \text { cas } 10.96 \\
& \text { 20.5 } \\
& \text { 2:8 } \\
& \text { ail }
\end{aligned}
$$$$
\text { -4. }
$$

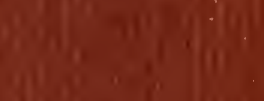

(i)

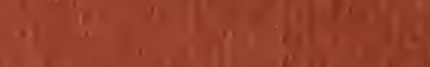
the

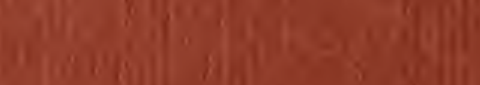
15. 1.

Mancingian ring

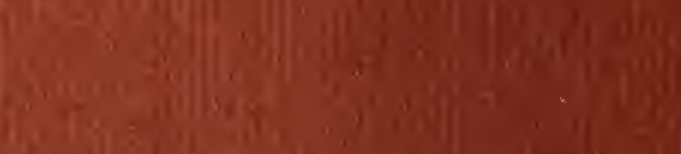

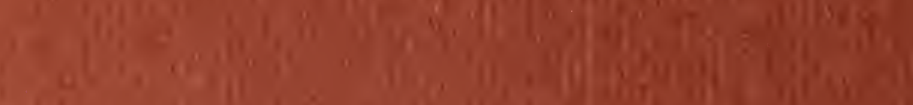
(4)

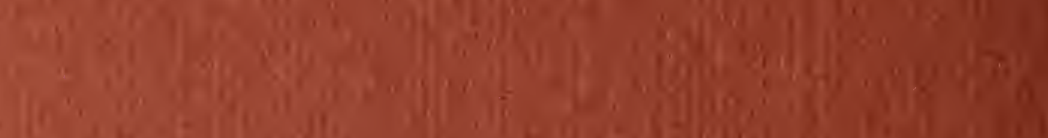
iIIII)

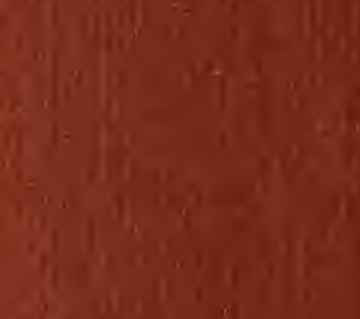
(1.)

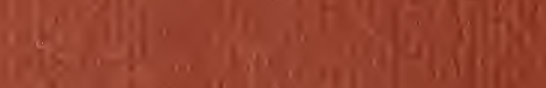
H.

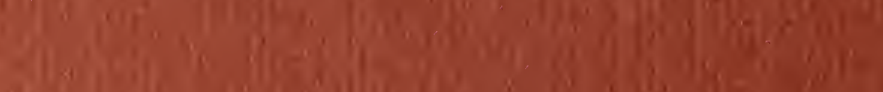
1)

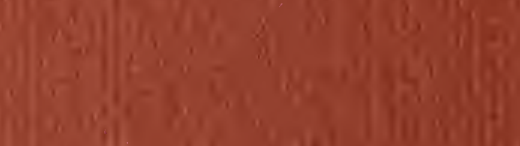
ing

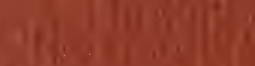

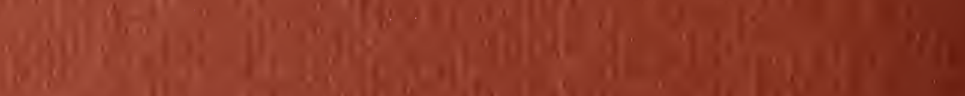

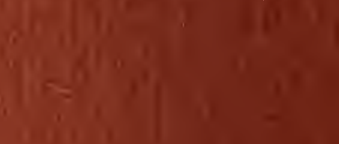
$\left.\log _{0}^{6}\right)_{3}$ $\cos (x)=2$

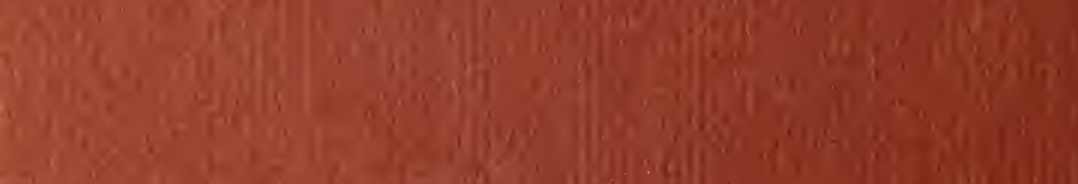

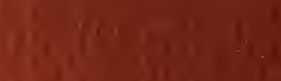


THE WHISTLER PEACOCK ROOM 


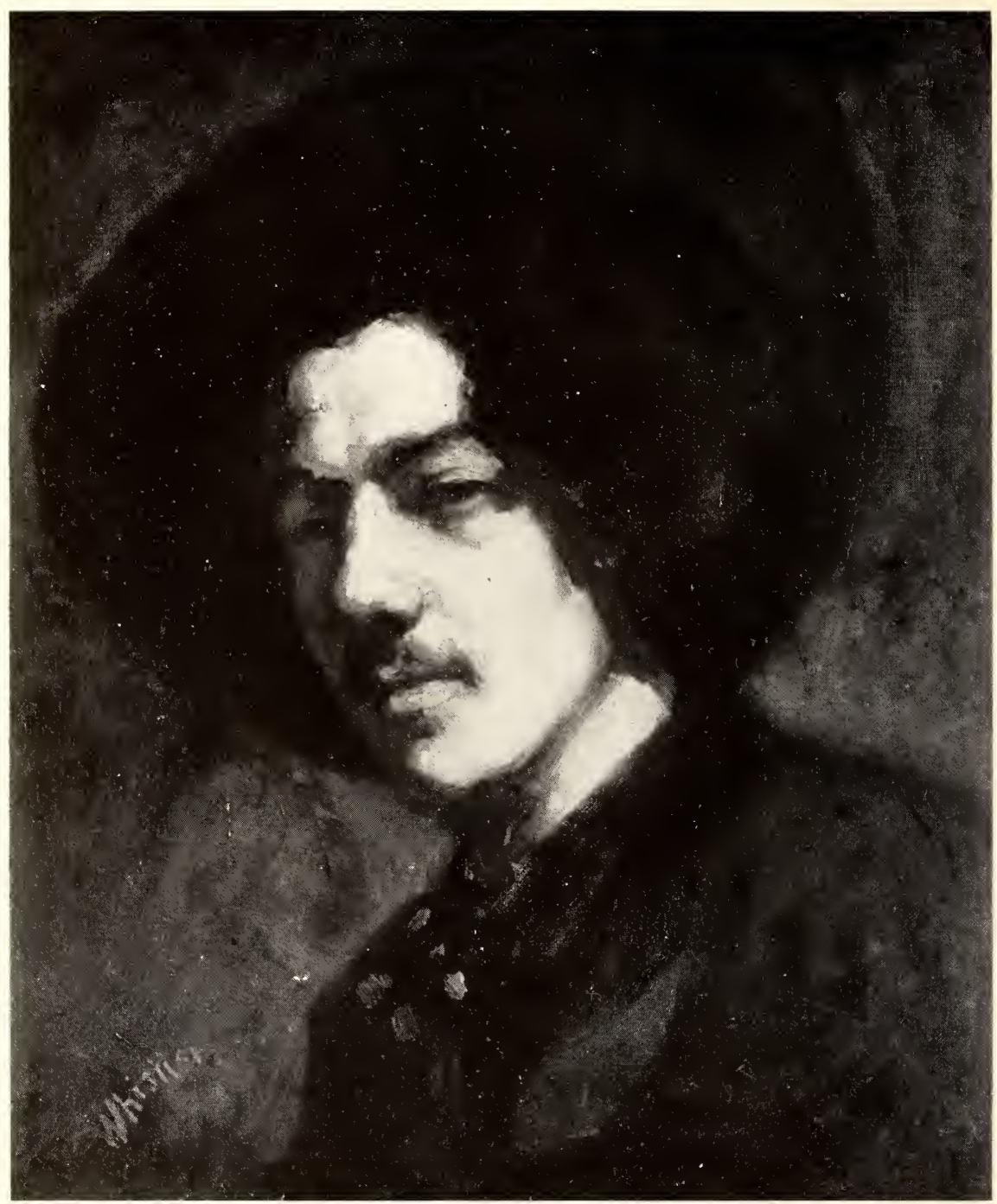

06.57. JAMES MCNEILL WHISTLER: PORTRAIT OF HIMSELF Oil painting, done in Paris, c. I 858 . 


\author{
The Freer Gallery of Art \\ of the \\ SMITHSONIAN INSTITUTION
}

\title{
THE WHISTLER PEACOCK ROOM
}

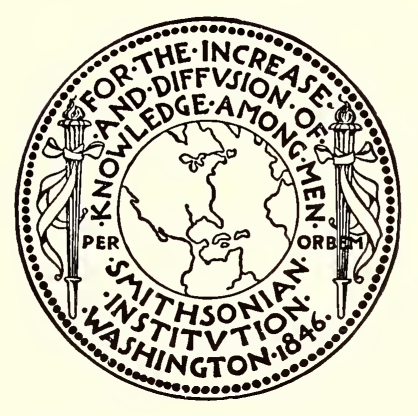

Publication 4024

WASHINGTON, D. C.

1951

Freer Gallery of Ant

Washington, D. C. 
Ebe Eord daftimore (pres BALTIMORE, MD., U. s. $A$. 


\section{FOREWORD}

The following account concerns two objects in the collections of the Freer Gallery of Art. These are treated in two sections, the first of which is properly called Harmony in Blue and Gold: The Peacock Room, with the catalogue number 04.6I. The second, number 03.9I, is a portrait known as Rose and Silver: the Princess from the Land of Porcelain, which hangs in the Peacock Room and around which the room decorations were designed. Each section is followed by a bibliography relating to it. 



\section{CON'TEN'TS}

Page

The Peacock Room ...................... I

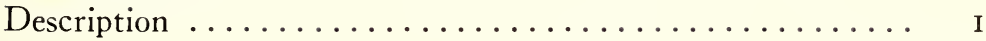

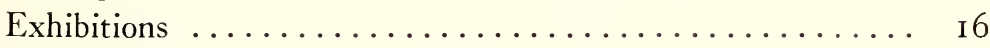

Bibliography ................... I6

The Princess from the Land of Porcelain............. I9

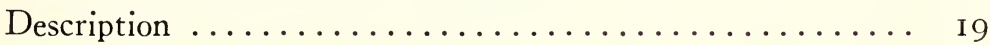

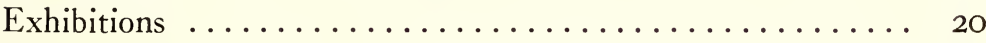

Bibliography ..................... 2 I 



\title{
HARMONY IN BLUE AND GOLD: THE PEACOCK ROOM
}

\author{
Painted during $1876-1877$ by \\ James A. McNeill Whistler ( I834-1903) \\ *** $*$ *
}

\section{DESCRIPTION}

The Peacock Room was decorated by James A. McNeill Whistler and is now installed as a part of the permanent collections of the Freer Gallery of Art and designated as Gallery XII. It is an oblong room with a high ceiling. At one end is a fireplace and mantel over which hangs Whistler's painting "La Princesse du Pays de la Porcelaine," or "The Princess from the Land of Porcelain"; at the opposite end is a built-in sideboard, above which is a panel depicting two peacocks. Along one side are three large shuttered windows and on the opposite side two doors. A paneled wainscot extends around the walls, above which is a series of brackets and shelves erected against the painted canvas and leather wall covering. The ceiling is paneled in geometric designs with eight pendent lighting fixtures.

Whistler's signature, the "Butterfly," may be seen at the top of the right shutter of the central window, in the southwest corner of the ceiling, on the upper left panel of the top of the sideboard, and again at the left end of the long panel over the sideboard.

The room is done in oil color and gold on wood, leather, and canvas; size, $4.258 \times$ I0.IO9 $\times 6.083$ meters (approximately I $4 \times 33 \times 20$ feet).

The Peacock Room was originally designed for use as a dining room and for the display of a collection of blue-and-white porcelain in the house known as The Mansion, located at No. 49, Prince's Gate, London. This was the residence of Frederick R. Leyland, a Liverpool shipowner and one-time president of the National Telephone Company of England.

Mr. Leyland had moved to London, bought the house, and engaged the well-known architect Norman Shaw to remodel and redecorate it. It was said that it was Mr. Leyland's ambition to live the life of a retired Venetian merchant prince in modern London, and he spared no expense or trouble to make the house fit his dreams. He had bought and had instalied in the house the famous Percy staircase, which once adorned Northumberland House before that famous landmark was torn 
down to make room for an avenue of the same name. The staircase was of stone, with a gilded-bronze balustrade and a paneled dado running from the lower hall to the upper landing. The lower landing was just to the left of the present main door to the Peacock Room. Whistler had been called in to enrich the panels of the staircase, which he did by imitating aventurine lacquer decorated with small floral patterns in pale pink and white, somewhat in the Japanese taste and style. The panels from this dado also form a part of the permanent collections of the Freer Gallery of Art.

Among the many paintings that Mr. Leyland had acquired was Whistler's "Princess from the Land of Porcelain," which was to hang in his dining room and, according to Leyland's plans, was to form the central theme in a scheme of Oriental splendor. It was to be surrounded by a fine collection of blue-and-white porcelain, and thus "The Princess" was to become truly what her title implied.

Murray Marks, a friend of both Leyland and Shaw, played a major role in the decorating of the house, acting as adviser to both men, and it is said that it was Marks who selected most of the blue-and-white porcelain that was to go into the dining room.

Shaw had as an assistant a young architect named Henry Jeckyll who, it seems, was mainly responsible for the introduction into England of Japanese methods of decoration in domestic architecture after the Paris Exposition of I 867. Notable among the examples of his work were the billiard room and a fireplace and mantel in the house of Alexander Ionides in Kensington. To Jeckyll was entrusted the task of remodeling and decorating the dining room, and he built into the existing architectural features of the room a complete though flimsily constructed wooden shell. It was this important fact, perhaps an unintentional one on Jeckyll's part, that has made it possible to dismantle and re-erect this famous room four times during its existence, although not without some damage to the decorations, in 1904, 1905, again in 1920, and most recently beginning in 1947 .

Jeckyll erected walls, a paneled ceiling with eight pendent lamp fixtures, and full-length shutters over the three windows, and built a turquoise-blue fireplace at one end of the room, over the mantel of which he fitted a niche for "The Princess." Seeking a suitable wall covering, he had obtained, at a cost of about $£$ I,ooo, a quantity of fine old Spanish leather, which had been brought to England by Catherine of Aragon and had hung for 300 years or more in a Tudor house in Norfolk. Its whole surface was embossed with a cross-hatch and twisted-ribbon design and covered with German gilding-that is, silver leaf coated with amber shellac and thus made to resemble gold leaf. On the gilding was 


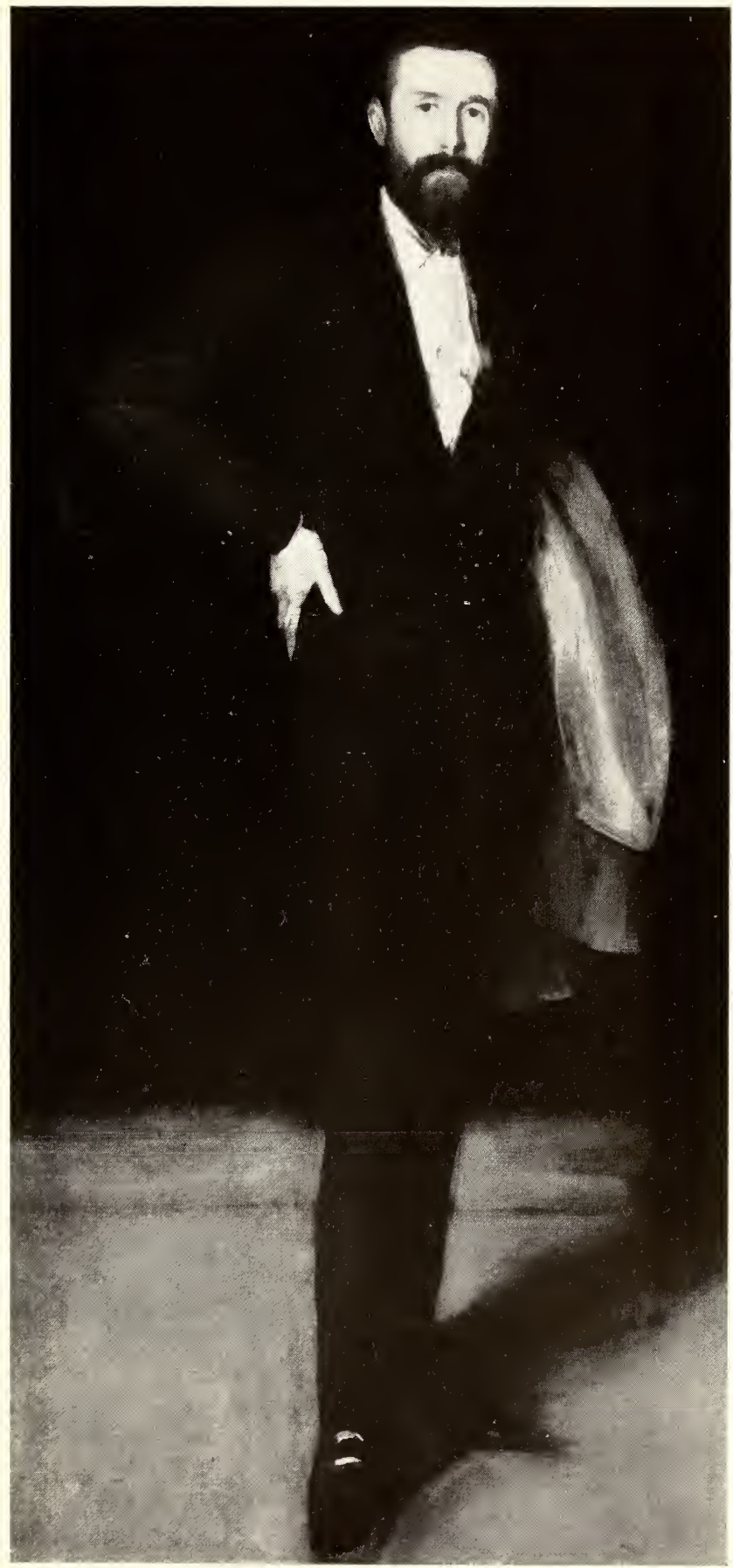

05,100. PORTRAIT OF F, R. LEYLAND: ARRANGEMENT IN BLACK

Oil painting, done in 1873 . 
displayed Catherine's device, the open pomegranate, and a series of small, richly colored flowers.

The walls and most of the ceiling were constructed of second-grade random widths of pine planks averaging about 6 inches wide by fiveeighths of an inch thick. These planks were grooved along the lateral edges and keyed together by loose-fitting splines. Canvas was applied to the planking on the walls, and this in turn was partly covered by leather, i.e., from the top of the second row of shelves to the ceiling. Apparently Jeckyll did not have enough Spanish leather to cover it all. The ceiling was constructed for the most part in the same manner as the walls, except that the geometrical patterns of the panels were designed to terminate in the eight pendent gas-light fixtures by an ingenious use of the molding. These pendent lamps were not confined to the dining room but were used generally throughout the main floor of the house. Canvas was glued to the ceiling also and the molding nailed over it. Its purpose, perhaps, was to enable the designer to cover up the cracks between the long pieces of grooved pine to form a flat surface, and this canvas was undoubtedly toned to match the walnut wood used in the lower parts of the room. It seems strange that, in view of the age and value of the leather covering, a more solid foundation, less subject to movement caused by atmospheric changes, was not provided, for over the years there was a constant and damaging movement of the foundation.

Against the canvas and leather on the walls Jeckyll erected around the room a series of walnut shelves, carved and gilded in the Japanese manner, for the display of the blue-and-white ware. The woodwork of the doors, shutters, and wainscot was of walnut too, which he covered here and there with a touch of gold, but, for the most part, it was varnished in a natural wood finish.

A rug with a red border was placed on the floor, the dining table with its ornaments and chairs was put in place, "The Princess" hoisted to her position in the niche assigned her, the blue-and-white porcelain carefully placed on the shelves prepared to receive it, and the dining room was complete.

It was said that another of Whistler's paintings, "The Three Figures: Pink and Grey," was to adorn the wall opposite "The Princess," but this part of the original plan was never carried out.

Just when Whistler had his first access to the finished room is unknown, but the date of his work is a matter of record: it was accomplished during a period of 6 months during the latter part of 1876 and the early part of 1877 ; and it must have been about that time that he was invited to view the finished room. It is said that he was pleased with the place of honor accorded "The Princess" but objected to the 


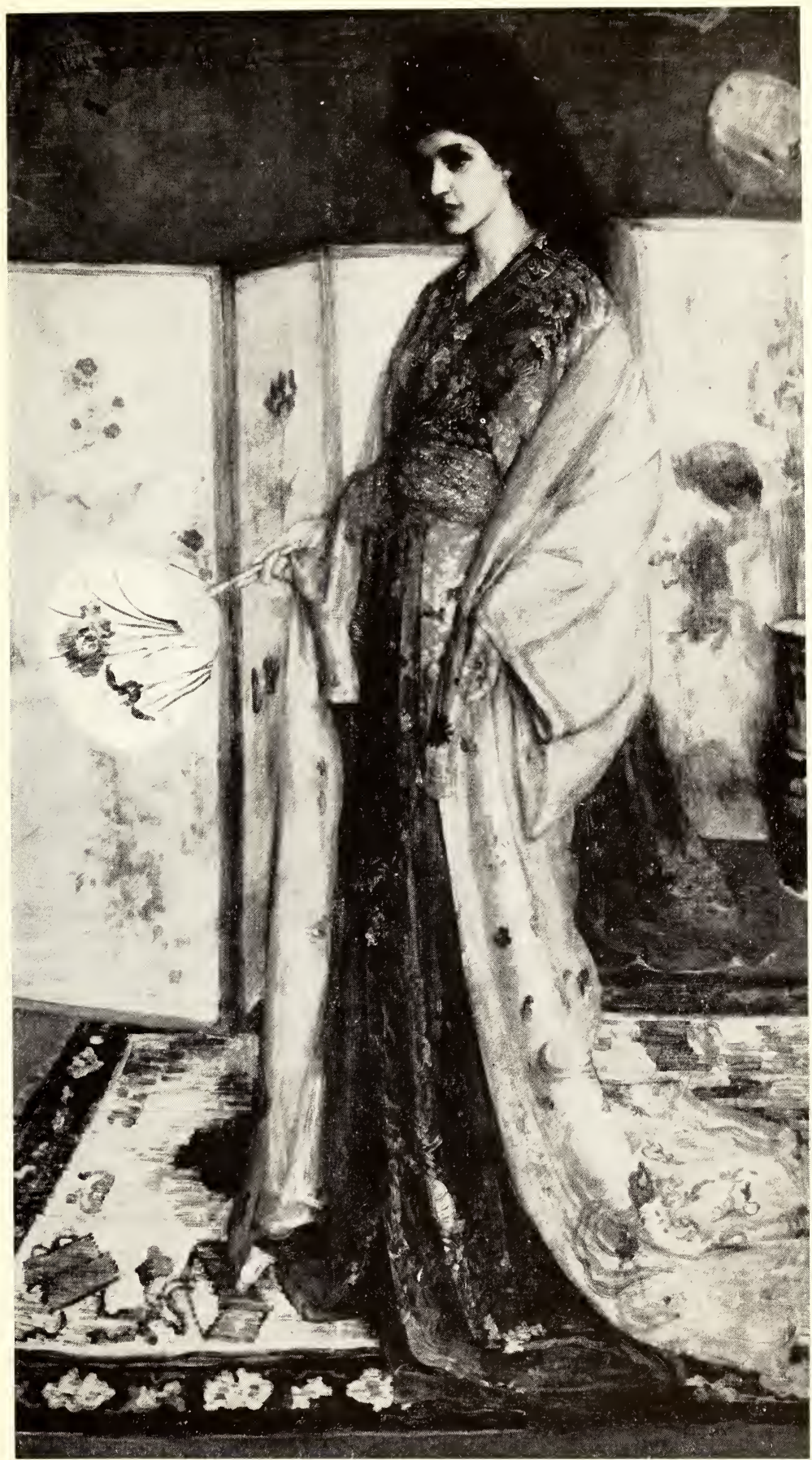

03.91, ROSE AND SILVER: THE PRINCESS FROM THE LAND OF PORCELAIN

Oil painting, done in $1863-1864$. 
surroundings on the grounds that the red flowers, the gilded leather, and the red border on the rug were harmful to the delicate color arrangement of his painting.

Many stories of subsequent happenings relating to the room have been told and published in various places. Literally hundreds of articles appeared in newspapers, art magazines, and other periodicals of the time. From this welter of material, it is difficult to present fully and factually the true story of the room's transition into the Peacock Room. However, an account of intense interest does emerge from these many sources.

According to some writers, Whistler persuaded Leyland to allow him to tone down the room, and he started by painting out the red flowers and cutting off the red border of the rug. Next he tried Antwerp blue on the gilded leather, experimenting on the open spaces surrounding "The Princess"; this failed and he begged to be allowed to try something else. When the idea of the peacock motive was born or how he prevailed upon Leyland to allow him to proceed is unknown, but Whistler himself explains that the peacock served as a means to effect the desired arrangement of colors. Some stories have it that he took advantage of the owner's absence shortly after the initial effort; others, that Leyland agreed to let him proceed but with no idea how far he would go.

Whistler is said at one time to have broached a scheme of decoration using the peacock theme to W. C. Alexander for his house on Campden Hill, and to have gone so far as to draw a few sketches of the idea, but it was never carried out. Certainly there is no evidence that he had any such scheme in mind when he began the task of subduing the surroundings of his painting "The Princess." It is equally certain that the idea had not been forgotten; the "Peacock Room" is ample testimony to that. Whether by design or accident, peacocks and peacock feathers in gold on blue and blue on gold, with a dash of blue-green and green here and there, are the motives throughout. The scheme of decoration is Oriental in style but represents a modern and personal adaptation of the finest in Oriental art by a Western artist of genius.

The most important features of the decoration are the huge peacocks on the shutters, painted in blue on a gold ground, and the large panel showing two peacocks in gold on a blue ground at one end of the room. All the subsidiary decoration is developed from the breast and tailfeathers of the same bird.

Whistler's treatment of the ceiling is especially ingenious. First, he ripped off the canvas and applied gold leaf to the whole wooden surface; then, by using a simple convention founded on the "eye" of a peacock's 
tailfeather repeated in a circular fashion around the pendants supporting the Japanese type of lanterns, contrived to connect the star-shaped groups of polygonal panels. This added a somewhat Oriental character to the Tudor type of design of the entire ceiling.

Many stories are told of the work, its progress, and the interest aroused in an art-conscious London of the day. Some of Whistler's friends who knew him at the time affirmed that the actual painting was done entirely by him and that he employeed an assistant only in the gilding and lacquering of the flat surfaces. Realizing that the room would be used mostly at night and illuminated by gas light, he did most of the important work at night in order to obtain the desired effectat least that is the story. It is related also that he worked suspended from the ceiling in a hammock, that he used a brush attached to a fishing rod to touch spots too high to reach from a ladder, that both he and his assistant worked like mad, their hair covered with bits of gold leaf.

These accounts and many others, some true, some pure fiction, all contribute to the legend of this famous room. Although most of the work was performed during the owner's absence, a great part of it at night, it seems that Whistler's days were always occupied receiving callers - some, interested friends, some, curiosity seekers, and not a few, representatives of the press. Leyland was said to have objected strenuously to having his dining room used as a reception hall by Whistler without his permission.

It is apparent that some of the gilded leather was to be left intact; instead, Leyland found it completely covered with paint, and, according to Mortimer Menpes in his book, he asked Whistler what he owed him for wrecking his dining room. "A thousand guineas," promptly replied Whistler. "No," said Leyland, "I shall give you a thousand pounds." Whistler is said to have made no reply, but it is certain that he requested that he be allowed to finish the decoration of the room, and Leyland was once more turned out. Whistler completed his operations, painting upon the huge panel at the end of the room opposite "The Princess" a caricature of himself and Leyland in the form of two peacocks, one with its body smothered in gold coins, claws clutching a mass of silver shillings, the other prancing and triumphant in disdain, the air filled with flying feathers. "Thus," says Mr. Menpes, "was the story of the odd shillings recorded for all time."

This last bit of decorative art on the long panel at the end opposite "The Princess" occupied the space where Whistler had hoped to see his painting "Three Girls" hanging, and he had left that end until the last. After the quarrel and after he had conceived the idea of painting the two peacocks in the space, he was faced with the necessity of providing 

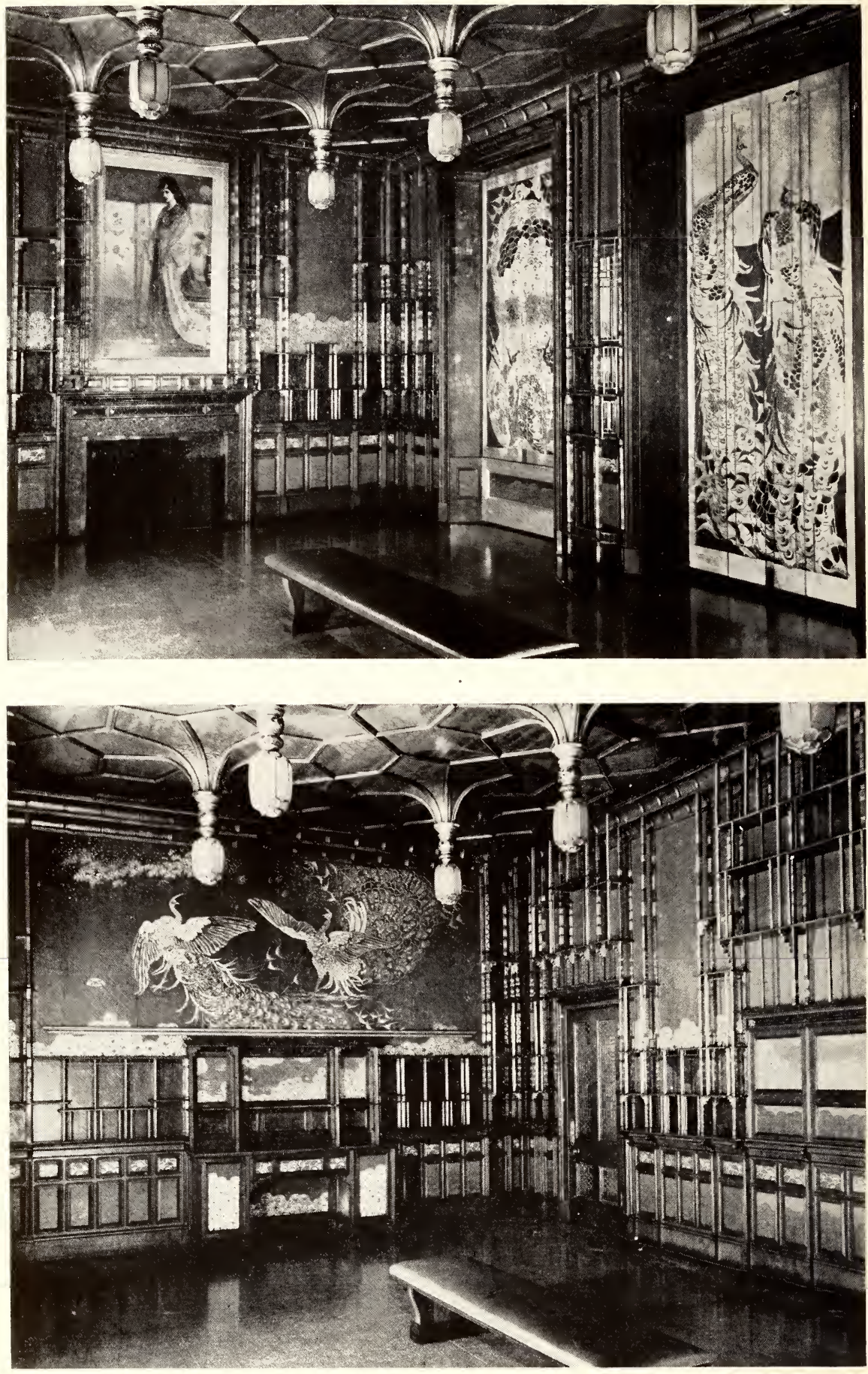

04.61, HARMONY IN BLUE AND GOLD: THE PEACOCK ROOM

Oil color and gold on wood, leather, and canvas. Painted during $1876-1877$. Upper, northeast corner; lower, southwest corner. 
some kind of an ornament or fixture to fill up the space beneath the panel-hence, the sideboard. This was designed by Whistler and built to his order and represents the only architectural feature of the room with which he is connected.

Another and perhaps more plausible version of the creation of the design of two peacocks on the large panel is that it refers to the relations that Whistler always felt existed between an artist and his patron. Whistler himself referred to it as depicting "the rich peacock and the poor peacock."

From the mass of conflicting stories there emerges the fact that no contract was ever drawn up for the Peacock Room decorations, although it is said that the original understanding was that Whistler was to receive 500 guineas for it; but inasmuch as the undertaking was so materially enlarged and the actual amount of work so much greater than originally planned, Whistler increased the price to 2,000 guineas, which Leyland refused to pay. He finally gave Whistler £I,OoO for it and was never wholly forgiven for what the artist regarded as an insult. All professional men in England at that time were paid in guineas, and Whistler simply could not permit art to be treated as merchandise. $\mathrm{He}$ felt, therefore, that he was being robbed of his shillings and that the whole affair had taken on the aspect of a commercial transaction, although as a matter of fact he had derived a great deal of pleasure from the work with no thought of profit; hence, he took his revenge by painting his "patron" in the guise of a rich peacock clutching a pile of coins in his claws, and himself as a poor peacock, proud, defiant, and disdainful, spurning wealth.

Tragedy lurks about the Peacock Room, too. The story goes that poor Jeckyll, the architect who designed the room, came to examine the golden peacocks and blue background that had supplanted his gilded Spanish leather adorned with pomegranates and flowers and his walnut panels and shelves, and was cut to the quick. According to Theodore Child, Jeckyll had already suffered several disappointments due to accidents which had deprived him of the credit for certain of his works, and all his hopes were centered on his efforts in Leyland's house. When he saw his handiwork obliterated and heard everyone talking of Whistler's work, it was too much for his mind. They found him afterward babbling incoherently of fruit and flowers and peacocks while he feverishly worked at gilding the floor of his bedroom. Soon afterward he died without recovering his reason.

Whistler was proud of his achievement, and it is said that he stated, "Pictures have been painted often enough with consideration of the room in which they were to hang; in this case I have painted a room 
to harmonize with my picture"; but it is certain that at least three others were disappointed with the result. Murray Marks, for one, was from the first opposed to changing the room. In his opinion the room, as Jeckyll left it, was perfectly suitable for what Leyland considered its chief beauty, the blue-and-white porcelain on the shelves; but in spite of his opposition, Whistler prevailed.

Leyland can hardly be blamed for his disappointment over the so-called destruction, or at least the complete obliteration under a coat of turquoiseblue paint, of the famous Spanish leather, which had historical connections and is said to have cost over $£$ I,000. From his point of view Whistler had really destroyed it. Poor Jeckyll's disappointment, too, has been mentioned and has added a somber note to the history of this famous room. It is said, however, that both Leyland and Marks eventually came to feel that the room was a masterpiece of interior decoration, although not suitable to the display of the blue-and-white porcelain as originally planned; indeed, Leyland never used the shelving for its original purpose after Whistler completed his work, apparently feeling that little porcelain was needed in the room, that it was a much finer piece of decoration without it.

For the next few years little was heard about the Peacock Room until 1892, when Mr. Leyland died and the house and its contents were sold at auction. "The Princess" passed into the hands of Alexander Reid at the sale of Leyland's paintings, but the Peacock Room remained in the house. According to Arthur Jerome Eddy, after the house passed to its new owners an occasional visitor was allowed to view the room, but it no longer served as a setting for the painting. In the place of "The Princess," a large mirror filled the niche, and the shelves were occupied by books. "But," wrote Mr. Eddy in 1903, "the decoration is in good condition, and could the walls and ceilings be removed and 'The Princess' restored to her place, the original effect could be reproduced."

Among the interested visitors who viewed the room after $\mathrm{Mr}$. Leyland's death was Charles L. Freer, the founder of the Freer Gallery of Art. For many years Mr. Freer had been quietly collecting Whistler's works, and in a letter from Mr. Freer to Howard Mansfield mention is made of a visit to "The Mansion" in London, where Mr. Freer was allowed to see the famous room. This was in 1902, and although Mr. Freer was not too highly impressed with it as a whole he expressed a desire to own the large panel at the end of the room and the three sets of folding shutters. He was under the impression that any effort to move the room in its entirety would prove disastrous to its decoration.

In 1903 Mr. Freer bought the painting "The Princess" and had it shipped to his home in Detroit, perhaps with no thought in mind that 
the room would ever become available for purchase. Before the year had ended, however, he was advised that the owners were contemplating the sale of the house.

The disposal of the room was placed in the hands of Messrs. E. Brown and Phillips, of the Leicester Galleries, London, and it was bought by Obach \& Co., I68 New Bond Street, London. This firm had the room examined by expert craftsmen, who reported that it could be dismantled and re-erected without undue harm because of its shell-like construction, and went ahead with plans for its removal and re-erection at their galleries for sales purposes. The job took some time, and their plans called for a formal opening for public view in June 1904. Meanwhile, early in January, they offered Mr. Freer first chance at its purchase, and he reiterated his desire to acquire the large panel and shutters and made an offer for them. He was still under the impression that removal of the room without serious damage would prove impossible. Even after Obach \& Co. had informed him that they had succeeded in dismantling the room, he cabled them that he could not use the whole room and repeated his former offer.

Negotiations continued until February I I, 1904, when the firm cabled Mr. Freer that they had had to take the room in its entirety and preferred to dispose of it in like manner, and offered Mr. Freer first chance at its purchase. He immediately wrote them for complete information regarding its construction features, which they promptly supplied along with the suggestion from Gustave Mayer, manager of Obach \& $\mathrm{Co}_{0}$, that perhaps Mr. Freer could rebuild it and place "The Princess" once again in her proper setting. Mr. Freer agreed to consider the proposal and asked for time to give more thought to the matter and made arrangements to go to London to see the room, which by this time was almost completely re-erected. He arrived there on May 15, 1904, and on the next day consummated its purchase and arranged for its dismantling, packing, and shipping to America.

It is evident that Mr. Freer gave his generous consent to a reasonable continuance of public display of the room at Obach's Galleries, and the exposition was continued until mid-July. Mr. Freer always had been extremely reticent about his purchases of objects of fine art, and he extracted a promise from Obach \& Co. to keep his name secret, preferring to divulge his purchase of the room himself in due time. They seem to have kept their part of the agreement, but the fact of the sale leaked out and aroused a storm of speculation and conjecture both in America and England. Final shipment was made from Southampton on September Io, and the various boxes and crates arrived in Detroit late in the fall. 

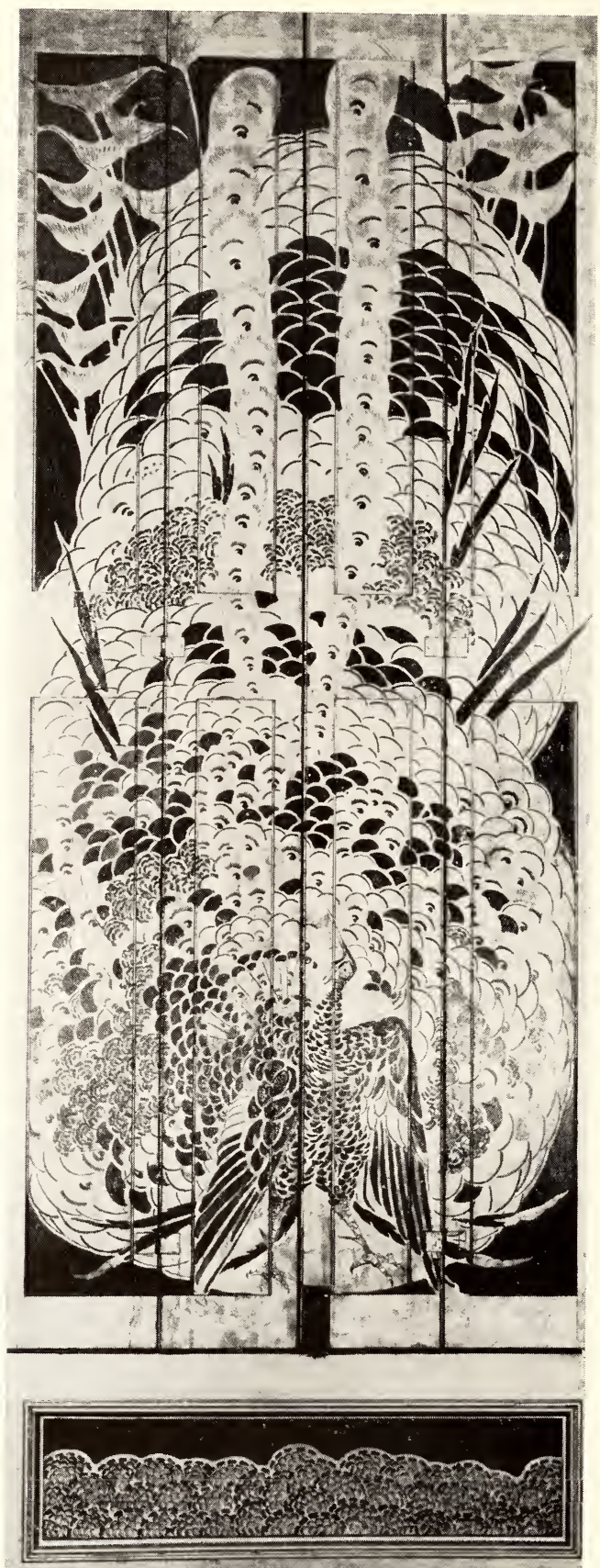

04.61. RIGHT SHUTTER IN THE PEACOCK ROOM 

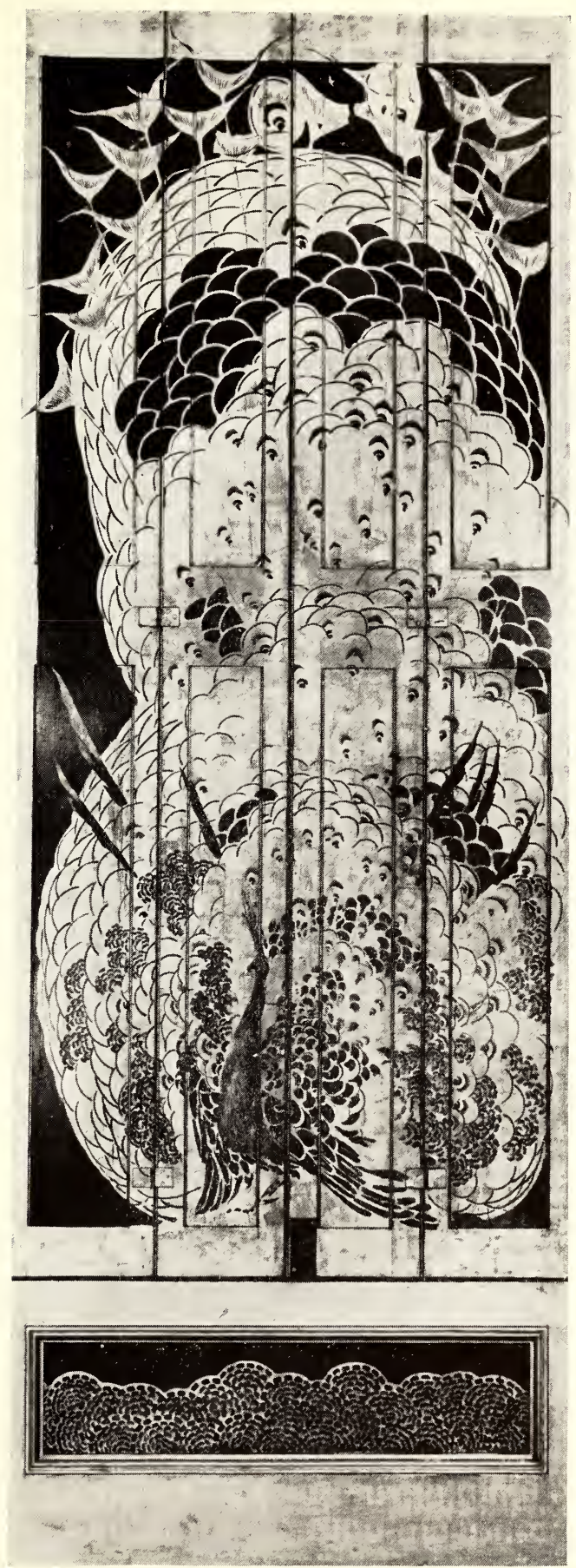

04,61. Left SHutter IN THE PEACOCK ROOM 
The following year Mr. Freer had an addition built to his Ferry Avenue home in Detroit and installed the room there, where it remained until 1919, when once again it was dismantled, shipped to Washington, D. C., and re-erected in its permanent location in the Freer Gallery of Art. Thus, the room bears the uncommon distinction of having been dismantled and re-erected four times during its existence, and is once again on display substantially as it was in Leyland's London home. Mr. Freer did not acquire the dining table, chairs, rug, or porcelain.

As has already been pointed out, movement caused by atmospheric changes in the flimsy foundation of the room has resulted in great, although not irreparable, damage to the walls and ceiling. This has necessitated occasional repairs such as those undertaken in 1926, when almost the entire ceiling was taken down and repaired, because of excessive cracking of the wooden surfaces. At the same time the leather covering of the large panel at the south end was slightly repaired. It became evident, however, that such measures were mere stopgaps and that a thorough overhauling was required if the room were to be saved. Plans made in 1942 for repairing the room were interruped by the war, and only minor repairs to the south panel could be made. In 1947-1948, however, the shell forming the upper wall was completely dismantled. An entire new shell was built in units of panels constructed of plywood coated with plastic on both sides and strongly cradled against warping. The leather was cleaned, treated, and mounted by floating onto the panels with a wax adhesive. The same process of mounting was applied to the canvas below the leather. The panels, although attached securely to the walls, may be removed without damage in case that should ever become necessary. In 1949, the ceiling was removed and properly cared for, and there is no doubt that the entire room will be able to withstand the ravages of time and atmospheric changes, and the chances are good that this, the most ambitious of Whistler's attempts at interior decoration, will be preserved for a long time to come.

The difficult task of transferring the leather and canvas from the old base to the new, as well as the entire job of restoration, was placed in the capable hands of John A. Finlayson, one of the restorers at the Museum of Fine Arts, Boston, Mass., and his equally skilled brother, Richard M. Finlayson, of Boston.

Whistler called the Peacock Room "Harmony in Blue and Gold," with the subtitle "The Peacock Room," and although the main part of that title seems to have fallen into disuse, it follows a pattern set by the painter in giving color combinations first place in most of the titles of his paintings. There were in the galleries in which his exhibitions were held a white-and-yellow gallery for his Venetian etchings, a rose-and-white 


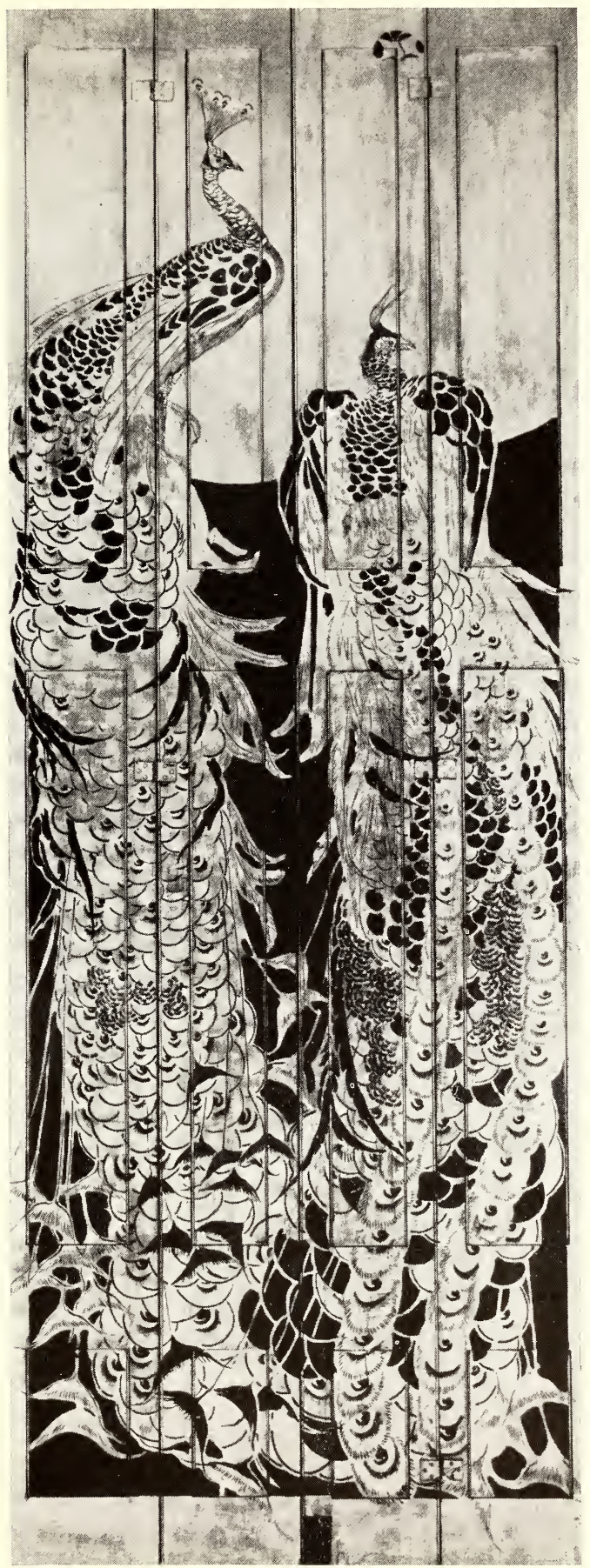

04.61. Center Shutter in THE PEACOCK ROOM 
gallery for his water colors. In his own houses there were the blue dining room in Tite Street, with purple fans floating on the walls and its goldfish bowl; the blue-and-white dining room at Cheyne Walk; the gray-and-black studio in which his mother's portrait was painted; and rooms in the houses of friends for which he designed the color schemes. None of them has survived, and we know of them only from books and articles written about him. But in the Peacock Room we have perhaps his greatest effort at interior decoration-certainly his most successful. This is probably the only surviving example of Whistler's work as an interior decorator. It represents his supreme effort at surrounding art with art; it is, in reality, a frame for "The Princess."

\section{EXHIBITIONS OF THE PEACOCK ROOM}

$1904 \ldots . . . . .$. Obach \& Co. Galleries, London.

1905-1919 ........ Charles L. Freer's residence, 33 Ferry Avenue, Detroit, Mich. (Exhibited privately.)

Since $1920 . . . \ldots$.... Freer Gallery of Art, Washington, D. C.

\section{[Now 71 East Ferry Avenue]}

\section{BLIOGRAPHY}

Anonymous.

1923. The Freer Gallery of Art, Washington, D. C. Architecture, September, pp. 293-297 (center shutter).

DaY, Lewis F.

I893. A Kensington interior. The Art Journal, [vol. 56], pp. [139]-I44. Illus. London. Influence of Japanese art on decoration by Mr. Jeckyll, and J. A. Whistler's gilding of the Peacock Room.

DURET, ThÉODORE.

I904. Histoire de J. McN. Whistler et de son oeuvre, p. 49 (detail). H. Floury, Paris.

Eddy, Arthur J.

I903. Recollections and impressions of James A. McNeill Whistler ..., pp. I28-I3I, 209. J. B. Lippincott, Philadelphia and London.

Freer Gallery of Art, Washington, D. C.

I 923-I946. Gallery book I2.

I 93I-I933. Combination gallery books, galleries 8-I2.

Grosvenor, Gilbert.

1923. The Capitol, wonder building of the world. The National Geographic Magazine, vol. 43, col. pl. I5 [p. 63I] (north wall of the Peacock Room in the Freer Gallery of Art).

HaRTMANN, SADAKICHI.

I910. The Whistler book . . ., pp. 21, 54, I03-I05, 2II. (Detail opp. p. I04.) L.C. Page \& Co., Boston.

Lane, James Warren.

[1942.] Whistler. Reproduction, p. 46. Crown Publishers, New York. 
Nomura Michi.

1908. Sekai isshū nikki. Diary of a journey around the world. Plate 3, Peacock Room as seen in Mr. Freer's house. Tokyo.

Obach Galleries, London.

1904. The Peacock Room . . . removed in its entirety from the late owner's residence and exhibited at Messrs. Obach's galleries ... London. OSBORn \& MERcer, London.

[1892.] The Mansion, formerly the residence of the late F. R. Leyland, esq., pp. 8-9. [Printed by T. Pettit \& Co., London.]

Pénneli, E. R. and J.

1908. The life of James McNeill Whistler ..., vol. I, pp. 198-209, pls. opp. pp. 20I, 204, 208 (details). W. Heinemann, London; J. B. Lippincott, Philadelphia.

I9II. Idem, 5th rev. ed., pp. I42-I5I, pl. (p. 212) (detail).

I92I. The Whistler journal ... Reproduction opp. p. Ioo; detail pen-andink sketches pp. 104, 105. J. B. Lippincott, Philadelphia.

Princep, Val C.

I892. The late Mr. Frederick Leyland's [collection] in Prince's Gate. The Art Journal, [vol. 56], pp. I29-138. Reproductions on pp. I32, I35. London.

RoBerts, E. G.

1925. Whistler in the Freer Gallery. American Magazine of Art, vol. I6, pp. 533-535. Washington, D. C.

SeItZ, Don.

1925. James Abbott McNeill Whistler; wit, wasp and butterfly. McClure's Magazine, n.s., vol. I, pp. 489-503. Reproductions (details) pp. 502, 503. New York.

SMITHSONIAN InSTITUTION.

[195I.] Brief guide to the Smithsonian Institution, 8th ed., p. 67. StOREy, Violet A.

1943. An impression of the Peacock Room. The Mayflower Log, October, pp. [2I], 35-37. Reproduction p. 2I. Washington, D. C.

WAY, T. R., and Dennis, G. R.

1903. The art of James McNeill Whistler, p. Iоo. (Detail, p. I02.) G. Bell \& Sons, London.

Williamson, G. C.

I9I9. Murray Marks and his friends, a tribute of regard . ., pp. 88-97. John Lane, London and New York.

Saarinen, Aline. The proud possessors; the 1ives, times, and tastes of some adventurous American art collectors. New York, Random House, 1958, pp. 129-132. 


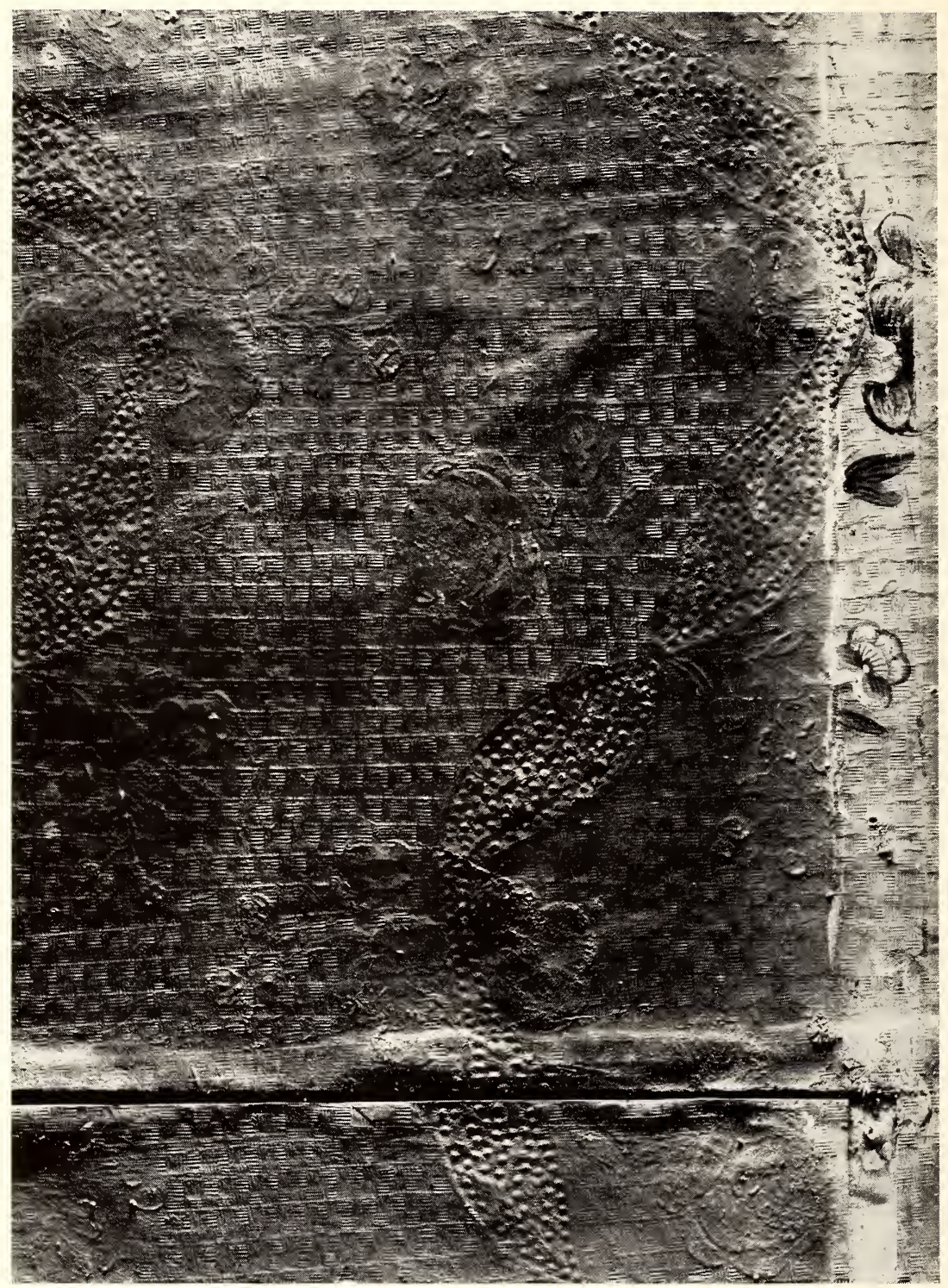

04,61, DETAIL OF THE LEATHER COVERING

Portion at right under a shelf bracket shows leather as it was before Whistler painted it. 


\section{ROSE AND SILVER: \\ THE PRINCESS FROM THE LAND OF PORCELAIN}

Painted during $1863-1864$ by

James A. McNeill Whistler (i 834-I903)

* * * *

\section{DESCRIPTION}

"The Princess" is a portrait of Miss Christine Spartali (later, Mrs. Edmond de Cahen), whose father was, at the time, Greek Consul General in London. Miss Spartali, at Whistler's request, posed for the portrait during the winter of $1863-1864$. Whistler had been working on the idea for some time before asking Miss Spartali to pose. It was one of the so-called Japanese paintings that engaged his attention so much during the period; others were the "Six Projects," "The Balcony," and "The Golden Screen," all of which are now in the Freer collections.

The painting depicts a standing figure of a young woman in a kimono; in her right hand is a circular fan; beyond her a sixfold screen. The kimono is gray and pink with red sash; hair, almost black; rug, blue and cream; fan, cream-white; screen, a lower value of cream-white with decoration in various tints; red-violet drapery and a blue jar in the background.

Signature: Whistler I 864.

The painting is in oil color on canvas; size, I.992 $\times$ 1.I 48 meters ( $78 \frac{3}{4} \times 45 \frac{3}{4}$ inches).

A much smaller version of the subject belongs to the Worcester Art Museum and bears the same title, although the face is Oriental in type, and neither kimono nor background is finished. The Worcester painting is one of several he did on a small scale while working out the idea for "The Princess."

It was said that Mr. Spartali did not care for the painting as a portrait of his daughter and, therefore, was not interested in buying it. D. G. Rossetti, warm friend of Whistler and admirer of "The Princess," was anxious to help him find a purchaser for it and had the canvas in his own studio for some time. One collector who admired it and wanted it found the Whistler signature distasteful to him and hoped it could be changed, but Whistler was unwilling to alter the offending name and the collector would not buy it. This episode is of interest because, as 
some writers have asserted, it served as a deciding factor in Whistler's decision to alter his signature on his future work, and these experiments finally brought forth the famous "Butterfly."

The first purchaser of the painting died shortly after its acquisition, and it passed into the collection of Frederick R. Leyland, a wealthy shipowner from Liverpool who had moved to London and who ultimately placed it over the mantel in his dining room-an act that led indirectly to the Whistler decorations of the Peacock Room.

"The Princess" was sold at the Leyland Estate auction at Christie's in London on May 28, I892, to Alexander Reid, a Glasgow dealer. Mr. Reid had had long and friendly relations with Whistler and, it is claimed, bought the painting on Mr. Whistler's account. Subsequent correspondence between the two men tends to show that upon Whistler's advice Reid held on to the painting for some time and eventually sold it for considerably more than it cost him. Also, while it was in his possession he generously lent the painting to Whistler for exhibition purposes, allowing it to be shown at the world's Columbian Exposition held in Chicago in I893. He finally disposed of it to William Burrell, of Glasgow, Scotland, from whom Mr. Freer purchased it in 1903.

After the Peacock Room had been bought by Mr. Freer, and reerected in Detroit, Mich., "The Princess" was placed again in the room over the mantel. Subsequently, of course, when the Freer Collection was transferred to Washington, it once again became an integral part of the famous room and now forms the central theme, framed, as Whistler intended, in its original surroundings.

EXHIBITIONS OF THE PRINCESS FROM THE LAND OF PORCELAIN I $865 \ldots \ldots \ldots$ The Salon, Paris.

I $872 \ldots \ldots \ldots$ International Exhibition, South Kensington, London.

I $892 \ldots \ldots$. . . . . Portrait Painters' Exhibition, London.

I $893 \ldots \ldots \ldots \ldots$. . . . . World's Columbian Exposition, Chicago. (No. I IOO.)

I $898 \ldots \ldots$. . . International Society of Sculptors, Painters and Gravers, London. (No. I80.)

I903-I9I9 ........ Charles L. Freer's residence, 33 Ferry Avenue, Detroit, Mich. (Exhibited privately.)

I904 .............. Copley Society's loan collection of Whistler's work, Boston. (No. 32.)

I905 ...........Whistler Memorial Exhibition, Paris. (No. 9.)

Since $1920 \ldots . . \ldots$. Freer Gallery of Art, Washington, D. C. 


\section{BIBLIOGRAPHY}

BÉNÉDITE, LÉONCE.

1905. Whistler. Gazette des Beaux Arts, vol. 34, pp. I48-I49, pl. opp. p. I48. Paris.

Bowdoin, W. G.

I90I. James McNeill Whistler, pp. I8-19, pl. [3]. M. F. Mansfield \& Co., New York and London.

CARTer, A. C. R.

1892. The art sales of I892. The Art Journal, [vol. 55], p. 285. (Sale of "La Princesse du Pays de Porcelaine" to Mr. Reid on May 28, I892.) London.

Dartmouth, Thomas.

I898. International art at Knightsbridge. The Art Journal, [vol. 6o], pp. 249, 25 I. London.

DEWHURST, W.

I904. Impressionist painting, pl. opp. p. 9I. George Newnes, London.

Dreyfus, Albert.

1907. James Abbott MacNeill Whistler. Die Künst, vol. 8, p. 213. München.

Duret, ThÉODORE.

1904. Histoire de J. McN. Whistler et son oeuvre, pp. 29, I48. H. Floury, Paris.

FELL, H. G.

1935. Memories of Whistler, No. I. The Connoisseur, vol. 95, No. 40I, p. 2 I. London.

Freer Gallery of Art, Washington, D. C.

I923. The Peacock Room by James McNeill Whistler. Gallery book I2. May.

Grosvenor, Gilbert.

1923. The Capitol, wonder building of the world. The National Geographic Magazine, vol. 43, col. pl. I5 [p. 63I] (north wall of the Peacock Room in the Freer Gallery of Art with "The Princess").

HadLey, Frank A.

I903. Whistler, the man, as told in anecdote. Brush and Pencil, vol. I2, illus. p. 345, Chicago.

HARTMANN, SADAKICHI.

I910. The Whistler book, p. 54, pl. opp. p. 50. L. C. Page \& Co., Boston.

LANE, James WarRen.

1942. Whistler. Illus. p. I03. Crown Publishers, London.

LAVER, JAMES.

I930. Whistler, pp. 107-108, pl. preceding p.217. Faber and Faber, London. Macfall, Haldane.

1905. Whistler. Frontispiece. T. N. Foulis, Edinburgh and London.

Pennell, E. R. and J.

1908. The life of James McNeill Whistler, vol. I, pp. I2I-I25; vol. 2, pl. opp. p. 224. W. Heinemann, London; J. B. Lippincott, Philadelphia. I9II. Idem, 5th rev. ed., pp. 86-88, pl. opp. p. II6.

Pousette-Dart, Nathaniel J.

1927. James McNeill Whistler, pl. 5. Frederick A. Stokes Co., New York. 
Princep, VAL C.

I 892. A collector's correspondence [Mr. Leyland]. The Art Journal, [vol. 55], pp. [247]-252. London. (Letters received from his artist friends, one of them being J. M. Whistler regarding "The Princess.")

Singer, Hans Wolfgang.

1905. James McNeill Whistler, pl. opp. p. 64. Charles Scribner's Sons, New York.

Storey, Violet A.

1943. An impression of the Peacock Room. The Mayflower Log, October, illus. p. [2I]. Washington, D. C.

WAY, T. R., and Dennis, G. R.

1903. The art of James McNeill Whistler, pl. opp. p. 32. George Bell and Sons, London.

Whistler, J. A. McN.

I905. L'oeuvre de James McNeill Whistler; quarante reproductions, pl. II. Libraries Centrale des Beaux Arts, Paris. 


19)

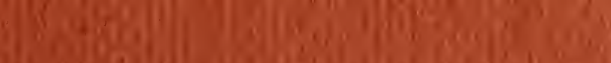

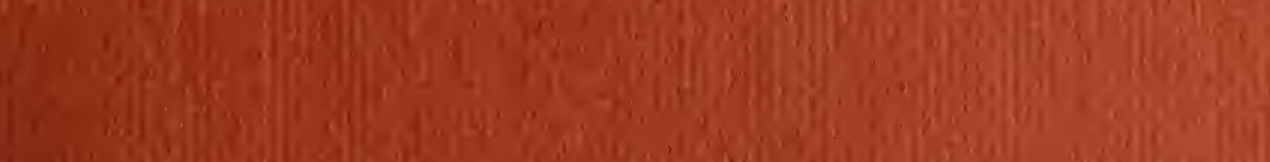
S. by Ifin . W.

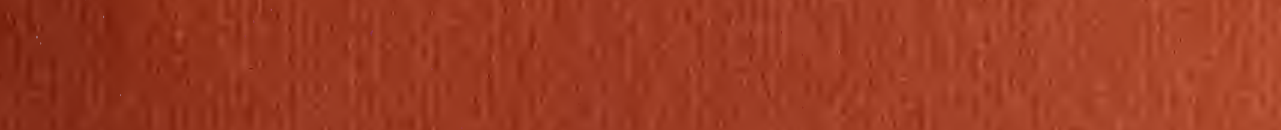

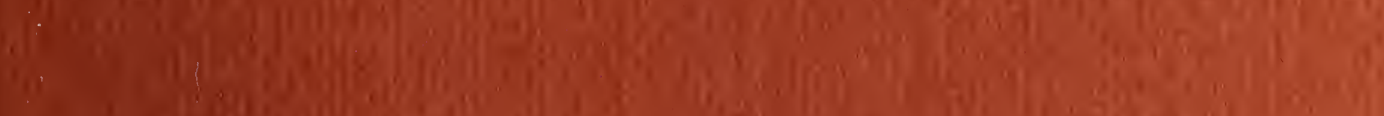

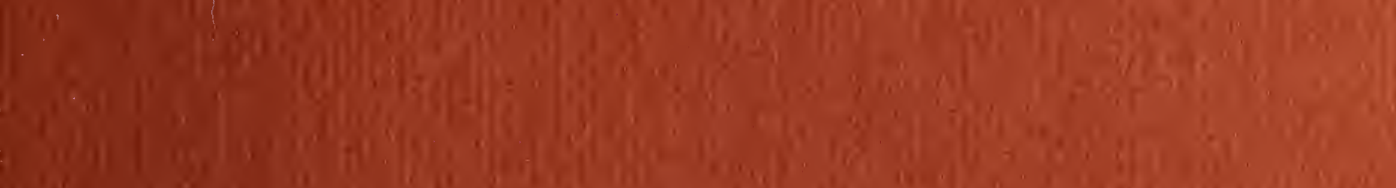
1.9. $\|$ I

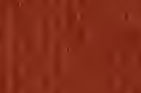
(1)

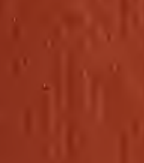

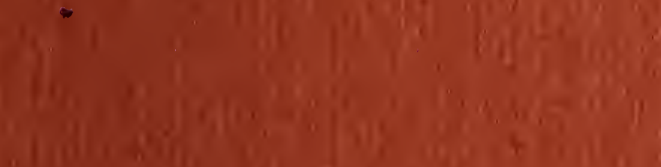

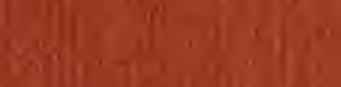
(1, $(3,1) \sqrt{3}$ ing

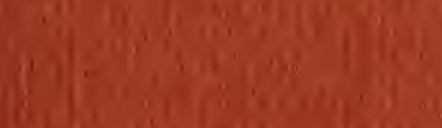

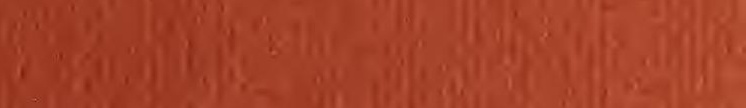
Sis

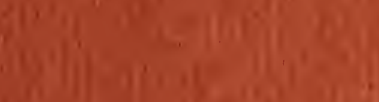
in

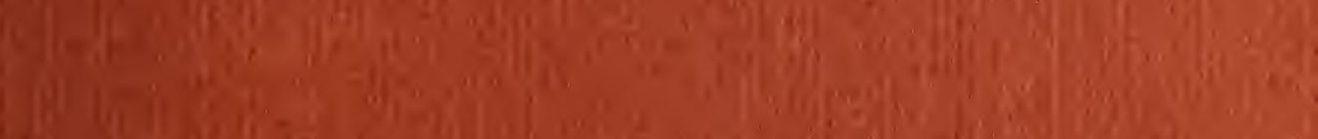
sing

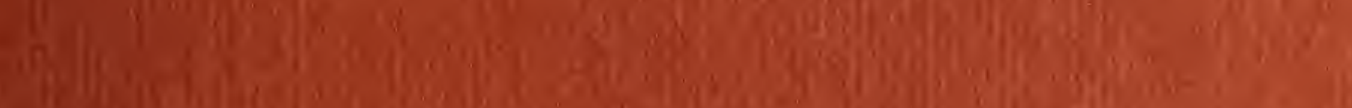

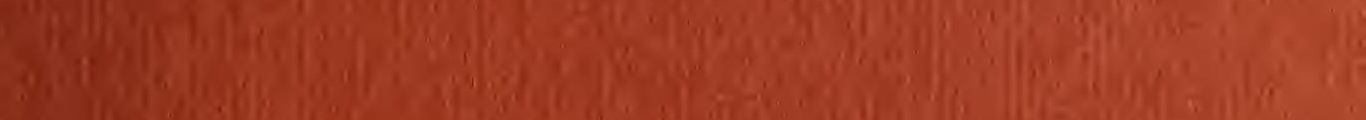
(1) If

the 


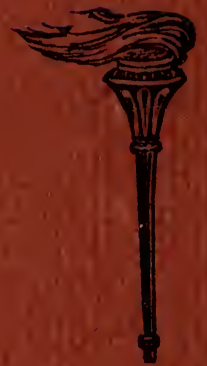

